\title{
Belém e a Academia do Peixe Frito: fisiognomias em Bruno de Menezes e Dalcídio Jurandir
}

\section{Belém and the Fried Fish Academy: physiognomies in Bruno de Menezes and Dalcídio Jurandir}

\author{
Carla Soares Pereiral | Katia de Souza da Silval (1) \\ Vanda do Socorro Furtado Amin (1) | Paulo Jorge Martins Nunes' (1) \\ 'Universidade da Amazônia. Belém, Pará, Brasil
}

\begin{abstract}
Resumo: Esta pesquisa integra um projeto que investiga a biografia e a produção literária e jornalística da Academia do Peixe Frito (APF), um grupo de intelectuais que se reuniu em torno de ideais de renovação literária e valorização da periferia, para refletir sobre questões sociais na Amazônia paraense, a partir de 1920. Objetiva-se perscrutar as relações entre a APF e a fisiognomia de Belém, por meio da observação dos espaços onde o grupo costumava se reunir e da análise de textos literários de dois de seus representantes: Bruno de Menezes e Dalcídio Jurandir. A pesquisa bibliográfica é embasada na teoria de Walter Benjamin acerca da cidade, retomada por Bolle (2000) e Gagnebin (2014), e nos estudos sobre a APF realizados por Coelho (2003), Figueiredo (2001), Larêdo (2012), Nunes e Costa (2016), entre outros. Os escritos analisados configuram-se como produções nas quais a cidade é o lugar onde os escritores são observadores que redesenham a fisionomia dela por meio da confluência de imagens do cotidiano e do imaginário social. Assim, a escrita de Dalcídio e de Bruno tem força poética, constituindo-se em imagens em movimento e experiências sensoriais entremeadas, as quais representam fragmentos significativos de Belém e do amazônida.
\end{abstract}

Palavras-chave: Academia do Peixe Frito. Literatura na Amazônia. Fisiognomia. Belém do Pará.

\begin{abstract}
This research is part of a project to investigate the biography and journalistic/iterary production of the Fried Fish Academy, a group of intellectuals who gathered around the ideals of literary modernization and valuing the periphery in order to reflect on social issues in the Amazon region of Pará state starting in 1920. This project is intended to examine the relations between this group and the physiognomy of Belém, the capital of the state, by observing the spaces where they gathered and by analyzing the literary works of two members: Bruno de Menezes and Dalcídio Jurandir. The bibliographical research is based on Walter Benjamin's theory about the city, which was resumed by Bolle (2000) and Gagnebin (2014), as well as research on this group by scholars such as Coelho (2003), Figueiredo (2001), Larêdo (2012), and Nunes and Costa (2016). The analyzed writings are productions in which the city is a place where these writers are observers who redesign its physiognomy through the confluence of everyday images and the social imagination. In this way, the writings of Menezes and Jurandir's have poetic strength, involving images in motion interspersed with sensory experiences which represent significant fragments of Belém as well as the Amazon.
\end{abstract}

Keywords: Fried Fish Academy. Literature in Amazon. Physiognomy. Belém do Pará.

PEREIRA, Carla Soares; SILVA, Katia de Souza da; AMIN, Vanda do Socorro Furtado; NUNES, Paulo Jorge Martins. Belém e a Academia do Peixe Frito: fisiognomias em Bruno de Menezes e Dalcídio Jurandir. Boletim do Museu Paraense Emílio Goeldi. Ciências Humanas, Belém, v. 14, n. 3, p. 1025-1043, set.-dez. 2019. DOI: http://dx.doi.org/10.1590/1981.81222019000300017.

Autora para correspondência: Carla Soares Pereira. Universidade da Amazônia. Avenida Alcindo Cacela. Belém, PA, Brasil. CEP 66060902 (carlasp21@hotmail.com).

Recebido em 19/12/2018

Aprovado em 25/04/2019
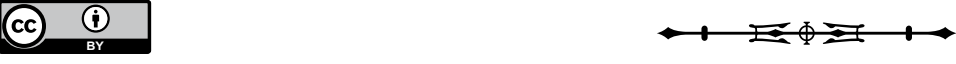


\section{INTRODUÇÃO}

Este artigo foi elaborado a partir de estudos desenvolvidos no projeto de pesquisa intitulado "Academia do Peixe Frito: interfaces entre literatura e jornalismo", do Programa de Pós-Graduação em Comunicação, Linguagens e Cultura, da Universidade da Amazônia (PPGCLC/UNAMA), em Belém do Pará. Implementado em 2016, esse projeto agrega pesquisadores da graduação e da pós-graduação stricto sensu, bem como professores pesquisadores da própria instituição e de outras parcerias, como da Universidade Federal Rural da Amazônia (UFRA) e da Universidade Federal do Pará (UFPA).

O objetivo do projeto de pesquisa é investigar a produção literária e jornalística dos membros da Academia do Peixe Frito (APF), uma associação informal de escritores, artistas e outros intelectuais que buscava impulsionar a literatura paraense, tanto em termos de produção quanto de publicação e divulgação de obras literárias e textos jornalísticos, cujos trabalhos iniciaram, provavelmente, a partir dos idos 1920, atravessando algumas décadas.

É importante dizer que alguns de seus membros, bem antes dos anos 1930, foram responsáveis pela introdução do Modernismo no Pará e no Brasil, apesar de suas obras dificilmente serem apresentadas na historiografia literária nacional (Inojosa, 1975; Figueiredo, 2001).
Pela relevância e originalidade das ideias e das publicações dos escritores da APF, há pesquisadores participantes do projeto, de diversas áreas, que desenvolvem suas dissertações e teses acerca da produção intelectual de alguns desses escritores (como Abguar Bastos, Bruno de Menezes, De Campos Ribeiro, Jaques Flores e Dalcídio Jurandir), sob os mais variados vieses. Desse modo, as pesquisas contribuem para a constituição de um saber e de uma memória sobre a Academia do Peixe Frito, que, irreverente e descolonizadora até no nome, fundou-se à margem da Academia Paraense oficial, na primeira metade do século $X X$.

Especificamente neste artigo, buscamos perscrutar as relações possíveis entre a Academia do Peixe Frito e a fisiognomia' da cidade de Belém do Pará, a partir da observação dos lugares onde o grupo costumava estar e da leitura analítica de textos literários de dois escritores ligados à Geração do Peixe Frito: Bruno de Menezes e Dalcídio Jurandir. Isso porque a atuação da APF revela profundas (e fecundas) ligações com o lugar de onde provinham os 'peixefritanos', com o lugar onde se reuniam, com o lugar em que habitavam, com o qual se construíam como sujeitos do seu tempo.

Assim, o espaço de Belém, do Pará e das Amazônias é ressignificado no contexto das obras dos 'rapazes' da Geração do Peixe Frito, visto que, de espírito modernista, esses escritores trataram dos assuntos tupiniquins sem serem bairristas ${ }^{3}$, problematizando nossa construção histórica, econômica, social e cultural, no contexto da

\footnotetext{
Empregamos o termo 'fisiognomia' no sentido benjaminiano para nos referirmos à leitura especulativa da imagem, esta como possibilidade de "[...] produção de conhecimento da história" (Bolle, 2000, p. 43), em distinção ao termo 'fisionomia', que remete ao sentido de aparência, semblante, feição, isto é, a aspectos exteriores do ser. Vale lembrar que o primeiro termo abrange um conceito relacional, em que se interpenetram a obra, o autor e o lugar histórico, por isso o conceito de fisionomia está contido no de fisiognomia.

2 Cunhamos, no grupo de pesquisa, essa denominação para nos referirmos aos intelectuais que participaram da Academia (ou Geração) do Peixe Frito.

3 Em 1924, Bruno de Menezes publicou o poema "Chapeleirinhas", na obra "Bailado Lunar". Nele, apresenta a mulher pobre, trabalhadora, e aborda o aspecto operário da Belém urbana dos anos 1920. Eis as duas primeiras estrofes: "Chapeleirinhas pobretãs dos olhos mansos:/É dessas mãos habilidosas/a trabalharem sem descanso/ dando vida às plumas, colorindo as rosas, / Que sahem esses chapéos ultra elegantes/ da menina leviana e da mulher 'coquette'” (Menezes, 1993, p. 77). Em 1932, Dalcídio Jurandir publicou o poema "Velho Mané Grigório", em que traz para a cena principal um vaqueiro, prático de fazendas, com toda sua sabedoria adquirida nos campos do Marajó. Eis alguns versos: "A febre do Arari matou meu amigo Mané Grigório [...]/ Mané Grigório me contava histórias/ [...] Aquela sua mão dura como o couro/ Quebrou muito boieco nos dias de ferra!/ [...] Curou bicheira dos bezerros/E puxou peito de vaca braba como onça,/ Que enchia as cuias de leite espumoso,/ Gostoso como luar na noite quieta/ da gente, trepada nos paus da porteira,/ comer carne com pirão de leite/ E ouvir histórias da Mãe do Fogo [...]" (Jurandir, 2011, p. 25).
}

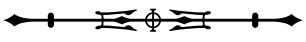


realidade da época ${ }^{4}$, a qual se refrata e chega ao contexto contemporâneo, para dizer sobre nossos vícios e virtudes (nossos e da cidade de Belém). Um grande exemplo de voz reacionária foi de Abguar Bastos: ainda na década de 1920, conclamava o Amazonas e o Nordeste para se unirem ao Pará e divulgarem o seu Modernismo para o restante do país; contrapunha-se à hegemonia cultural sulista e posicionava-se a favor do reconhecimento da diversidade linguística no Norte do Brasil, tudo isso expresso nos dois manifestos que lançou: "À geração que surge" e "Flami-n'-assu”, em 1923 e 1927, respectivamente (Figueiredo, 2001; Coelho, 2003).

Iniciamos este artigo com um breve histórico sobre a Academia do Peixe Frito, situando-a em seu espaço físico (geográfico) e discursivo. A seguir, discutimos a teoria na qual nos embasamos para a realização da presente pesquisa, a saber, o conceito de 'fisiognomia' de Walter Benjamin, tomado dos estudos de Bolle (2000) e Gagnebin (2014) sobre o pensamento do filósofo alemão, em diálogo com historiadores da literatura que empreendem discussão acerca da teoria de imagem, por ocasião do estudo do poema, como Bosi (1977) e Candido (1996).

Posteriormente, procedemos à análise do discurso literário do poema "Gente da estiva", de Menezes (2015a), e de trechos do romance "Belém do Grão-Pará", de Jurandir (2004, 2016), no intuito de observar como a fisionomia da cidade belenense é refletida nas referidas obras, levando-se em conta a correlação entre a presença do eu na cidade e da cidade no eu.

\section{O QUE É A ACADEMIA DO PEIXE FRITO?}

Lá eles se encontravam, comiam peixe-frito, bebiam 'umas' e contavam as novidades literárias [...] (Larêdo, 2012, p. 11).
A Academia do Peixe Frito (APF) foi um movimento literário e cultural formado por um grupo composto por jovens jornalistas, artistas e escritores, que se reuniam frequentemente em barracas e botequins no entorno do Mercado de Ferro, no Ver-o-Peso, em Belém, entre os anos de 1920 a $1950^{5}$ (Coelho, 2003). Ali, aos frames do vai-e-vem dos feirantes e do povo que frequentava o local, e servidos de pequenas postas de peixe frito, que acompanhavam os aperitivos, esses jovens refletiam acerca da sua realidade, manifestavam ideias e faziam literatura ao ar livre (Nunes; Costa, 2016).

Inicialmente, os jovens revolucionários que se reuniam para discutir e escrever literatura autodenominaram-se 'Vândalos do Apocalipse', título criado por Bruno de Menezes, fundador do movimento e da revista Belém Nova (1923-1929) (Figueiredo, 2001; Coelho, 2003), que fomentava o Modernismo paraense. $\bigcirc$ grupo teve ainda outros epítetos: 'Academia ao Ar Livre' e 'Associação dos Novos'. Depois, o grupo ganhava nova titulação: 'Academia do Peixe Frito'. A professora Terezinha Pacheco tenta esclarecer essa questão:

Bruno de Menezes participava dessa academia ao ar livre, que recebia diferentes epítetos, conforme a ocasião. No momento em que se reuniam no Ver-o-Peso, era a Academia Peixe-Frito. Eram encontros regados a aperitivos e, como tira-gosto, peixe frito. Em outras situações diziam ser Vândalos do Apocalipse por talvez estarem discutindo e anunciando a poética dos novos tempos. Tempos depois organizaram a Associação dos Novos para divulgar as novas ideias. (Pacheco, 2003, p. 167).

Identificar esse percurso por meio de datas específicas é um tanto complexo, dada a dificuldade de investigação em fontes históricas, já que o grupo era essencialmente

\footnotetext{
4 Devido a esse aspecto dessas produções literárias, alguns escritores da Geração do Peixe Frito são considerados literatos-etnógrafos pelos críticos, analistas e estudiosos de suas obras. Assim disseram, por exemplo, Reis (2012), Wanzeler e Pacheco (2016) e Wanzeler (2016) sobre Bruno de Menezes.

5 Segundo Coelho (2003, p. 51), os anos 1920 são o marco do surgimento da primeira geração do grupo de intelectuais renovadores paraenses. Na década de 1940, surge o Grupo dos Novos (1946-1952), do qual a APF foi predecessora.

6 Assim Ribeiro (1973) chamou os jovens que buscavam renovação literária nos anos 1920.
}

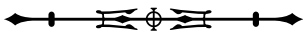


informal, o que significa que não havia atas de reunião nem anotações mais substanciais sobre sua atuação, que, diga-se, foi importante, senão essencial, para alavancar a produção literária paraense do século $X X$.

nome 'Academia do Peixe Frito' teve inspiração em uma prática de alimentação local muito comum entre os paraenses mais simples: o ato de comer peixe frito. À época, as postas de peixe frito eram vendidas em barracas populares pela cidade, a preços módicos, e as pessoas compravam-nas para complementar o almoço em casa ${ }^{7}$; também era o alimento barato e diário dos trabalhadores e frequentadores do Ver-o-Peso.

Assim, sem dúvida, consumir peixe frito era um marcador de identidade e de lugar social de desprestígio; por isso, a expressão que nomeou o grupo traduz muito bem a ideia de resistência e ruptura, proposta por esse movimento, e acentua o seu processo de identificação com o subalterno, com o excluído, com as classes trabalhadoras, com a periferia, com o negro, com os detritos sociais, com os espaços sem pompa, sem brilho e sem frescura ${ }^{8}$ da cidade de Belém.

Pela APF passaram, entre outros intelectuais, Bruno de Menezes, De Campos Ribeiro, Paulo de Oliveira, Ernani Vieira, Muniz Barreto, Arlindo Ribeiro de Castro, Lindolfo Mesquita, Sandoval Lage, Abguar Soriano de Oliveira
Bastos, Jaques Flores, Raul Bopp, Nunes Pereira, Edgard de Souza Franco, Farias Gama, Severino Silva, Rodrigues Pinagé, Clóvis de Gusmão, Dalcídio Jurandir, Santana Marques e Tó Teixeira (Figueiredo, 2001; Coelho, 2003; Castro, 2011; Larêdo, 2012) ${ }^{10}$.

O movimento desses 'moços' objetivava inicialmente romper com a política, com a estética canônica e, portanto, com o ilusório glamour parisiense da capital paraense, resquício da Belle Époque na Amazônia (1890-1912)11, exacerbada pela profícua (mas meteórica) economia da borracha no Norte do Brasil. Esses jovens peixefritanos lutavam por mudanças na seara das artes, desejavam mais engajamento da literatura nas lutas sociais e menos erudição, e não o faziam por pura rebeldia: o mundo estava em transição e o país passava por transformações desde o final do século XIX.

Dessa forma, o Modernismo do Pará acompanhou, paralelamente, as mudanças que ocorriam na Europa e, apesar de a estética parnasiana ainda estar presente nos textos produzidos no Brasil nas primeiras décadas do século $X X^{12}$, os jovens sentiam necessidade de modificações em diversas áreas, sobretudo nas artes (Figueiredo, 2001; Coelho, 2003).

A Geração do Peixe Frito surgiu, então, nesse contexto. Os jovens intelectuais que dela fizeram (p)arte

7 Essa informação pode ser lida numa crônica escrita por Flores (1947, p. 153), "Vamos comer peixe frito?", da obra "Panela de barro". Também no poema "A Academia do Peixe Frito", Marília Menezes, filha de Bruno de Menezes, menciona essa prática cultural. O poema de Marília foi apresentado no Sarau da Academia do Peixe Frito, na XXI Feira Pan-Amazônica do Livro, realizada em Belém do Pará, em maio/junho de 2017.

8 Termo coloquial que significa 'luxo', 'refinamento'.

9 Há outras explicações também possíveis para a escolha do nome 'Academia do Peixe Frito', mencionadas por Brito (2005) e Nunes e Costa (2016), as quais se correlacionam com a versão apresentada nesta pesquisa.

10 Destacamos que são esparsas as referências aos membros desse grupo, denominado de múltiplas formas: 'Academia ao Ar Livre', 'Associação dos Novos' - as quais surgiram e se uniram em torno da denominação 'Vândalos do Apocalipse', em 1921 (Figueiredo, 2001) -, 'Geração do Peixe Frito', 'Grupo do Peixe Frito', 'Academia do Peixe Frito'. Alguns pesquisadores citam uns membros, outros acrescentam um ou outro nome. Reunimos aí todos os citados nas pesquisas que realizamos. É importante também destacar que ainda não conseguimos comprovar a ligação direta de Eustachio de Azevedo, Remígio Fernandez e Vicente Salles com a APF, mas sim com as revistas na qual os membros da Academia publicavam.

11 Os historiadores divergem um pouco acerca dessas datações. Mas o fato é que as datas assinaladas compreendem o período de apogeu e queda da Belle Époque na Amazônia. No entanto, mesmo após a débaclé, ainda era possível perceber a forte motivação francesa na cultura belenense.

12 Bosi (2003), em "História concisa da literatura brasileira", fala desse fenômeno do fortalecimento do Parnasianismo no Brasil no final do século XIX e início do XX, em detrimento do Simbolismo, que abria caminho ao Modernismo na Europa ocidental.

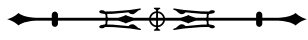


contribuíram para a construção de uma literatura no Pará que revela uma fisiognomia do lugar, no sentido benjaminiano. A propósito, é válido lembrar Adorno (2003), que, em relação às referências sociais nos textos literários, afirma: "A referência ao social não deve levar para fora da obra de arte, mas sim levar mais fundo para dentro dela. É isso o que se deve esperar, e até a mais simples reflexão caminha nesse sentido". (Adorno, 2003, p. 66).

A vasta obra dos escritores da APF apresenta-nos a sociedade amazônida, paraense e belenense a partir de seus conflitos históricos e culturais (ainda) mal resolvidos, não de forma estilizada, folclórica ou distante do leitor que vivencia as realidades locais, mas por meio de uma visão analítica e crítica de quem experimenta esse espaço de contrastes e de vozes dissonantes, que são as Amazônias.

Dessa forma, as feições da cidade redesenham-se por meio desses escritores, e o leitor se vê diante de novas percepções e expressões da Belém de outrora e da de agora. Em consequência disso, ele, no processo de recepção da obra, constrói um outro olhar sobre a cidade de Belém.

Nesse ponto, é importante esclarecer que os locais escolhidos pelos membros da APF para os encontros e para as reuniões do grupo são elucidativos de alguns aspectos de sua obra, especialmente de Bruno e de Dalcídio, uma vez que a fisionomia desses lugares é traduzida em alguns de seus textos com intimidade. Isso nos permite reconhecer a recriação desses caminhos nas trilhas do literário.

Para iniciarmos esse percurso, apresentamos, na Figura 1, um mapa de parte da cidade de Belém, no qual estão assinaladas as regiões onde se situavam os principais pontos de encontro dos escritores da APF.

Na Figura 1, os espaços coloridos de vermelho (áreas 1, 2 e 3) representam os lugares de reuniões constantes, ou seja, os mais visitados; já os de cor verde (áreas 4 e 5) significam locais menos frequentados (mas também importantes, onde aconteciam reuniões esporádicas do grupo) ou representam espaços de presença marcante em algumas obras ficcionais.

É importante dizer que nem todos os lugares citados por autores que já desenvolveram pesquisas relacionadas à APF ou aos seus membros (Figueiredo, 2001, 2016; Pacheco, 2003; Larêdo, 2012; Nunes; Costa, 2016; Wanzeler; Pacheco, 2016) estão assinalados no mapa (Figura 1). Por exemplo, em entrevista concedida a

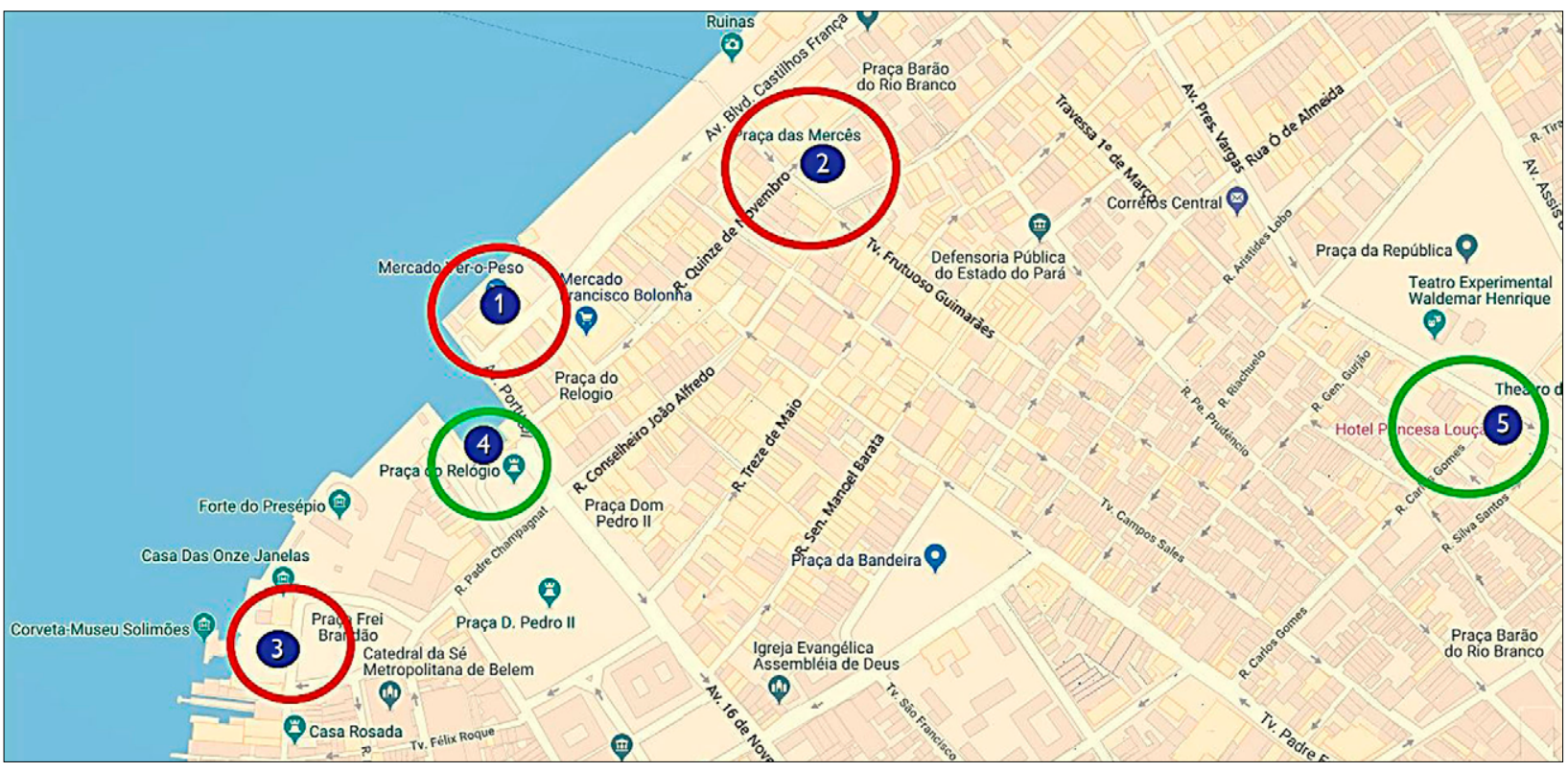

Figura 1. Mapa destacando a parte de Belém que localiza pontos de encontro dos membros da APF. Fonte: adaptado de Google Maps (2018).

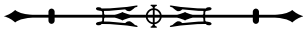


Reis (2012), Marilia Menezes, filha de Bruno de Menezes, afirma que a casa dele, no bairro da Cidade Velha (rua João Diogo, n²6), em Belém, também foi local de encontro do grupo, pois lá o pai recebia muitos amigos.

O mercado do Ver-o-Peso (área 1 na Figura 1) era o local de maior destaque nos encontros da APF, pois lá os jovens intelectuais se concentravam na maioria das vezes. Nesse complexo de barracas da feira livre, próximo às fritadeiras de peixe, situava-se o bar Águia de Ouro, botequim localizado sob uma das torres do Mercado de Ferro, na esquina, de frente para a avenida Portugal e para o antigo cais do porto (Larêdo, 2012). Pois bem, esse espaço do Águia de Ouro foi muito significativo para a APF, inclusive lá era o local de guarda da imagem de São Benedito da Praia, o santo dos pretos, para o qual ocorria uma grande festividade (Costa, 2011), marcando também parte da produção literária de Bruno de Menezes.

Não muito distante dali, situa-se a Garagem do Clube do Remo (área 3 na Figura 1), fundada em 1905, localizada na rua Siqueira Mendes, primeira rua de Belém. Nesse local, também se realizaram encontros da Academia. De lá, o grupo saía "[...] para as tertúlias ${ }^{13}$ e batalhas de confete do carnaval de rua de Belém [...]"14.

Os jovens acadêmicos também se concentravam no entorno da praça Visconde do Rio Branco, mais conhecida como Praça das Mercês ou Largo das Mercês (área 2 na Figura 1), local marcado por lutas do movimento cabano (1833-1836) (Borges, 2013), nos bares conhecidos, entre 1920 e 1930, como bar Carioca e bar Flor de Belém. Além desses, havia as reuniões no bar Barbinha, localizado na travessa Campos Sales, esquina com a 15 de Novembro (Larêdo, 2012).

Todos esses lugares contribuem para a constituição de uma identidade da Academia do Peixe Frito ${ }^{15}$ e, consequentemente, do ideário de literatos, artistas e jornalistas que fizeram parte dessa Geração. Assim, a cidade de Belém é cenário desses encontros, a partir dos constantes movimentos dos intelectuais em determinados pontos dela, o que colabora para a construção tanto de uma memória da cidade como do eu que a narra. Os peixefritanos, quando escreveram nela, sobre ela e sua gente, construíram, pelo tempo, uma memória de si, uma vez que constituíram suas obras a partir de elementos recriados desse espaço ${ }^{16}$.

Deleuze (1988), refletindo acerca das ideias de Immanuel Kant, afirma que o tempo do sujeito, esse tempo que marca o homem, e não somente as manifestações materiais, é inerente à memória. Essa marca temporal, referida por Deleuze (1988), é a própria história. A memória, aliada a ela, traduz-se como relação de afeto no sujeito; assim,

13 Festas de clubes que ocorriam geralmente nos domingos à tarde, independente das épocas carnavalescas. Aliás, até hoje os arredores da Garagem, na Cidade Velha, constituem um espaço marcado por esses eventos artísticos, que arrastam multidões em festa, como o Auto do Círio.

${ }^{14}$ Informação constante no roteiro da $7^{a}$ versão do "Trilhas no Literário", que tematizou a Academia do Peixe Frito. $\bigcirc$ evento, realizado em 18 de novembro de 2017, foi organizado pelo PPGCLC/UNAMA, sob coordenação do Prof. Dr. Paulo Nunes (UNAMA) e da Prof. ${ }^{2}$ Dr. ${ }^{a}$ Vânia Costa (UFPA) (Narramazônia, 2017).

15 Isso é perceptível porque a maioria dos lugares frequentados pelo grupo está marcada pela presença popular, sobretudo o mercado do Ver-o-Peso. Ali estão os negros, os pobres, as gentes de pé no chão; ali, as pessoas comuns trabalham, vendem, compram, ganham o pão de cada dia, descarregam peixe, açaí, estivas em geral, bebem, almoçam e labutam de novo. Nos bares espalhados pela Belém dos anos 1920, 1930, 1940, há as longas prosas animadas, a bebida, o divertimento, a música. Os peixefritanos, então, congraçaram o espaço simbólico de lutas via linguagem (jornalística ou poética) ao espaço físico da feira popular e das suas preferências pessoais, visto que muitos deles (senão todos) eram boêmios.

16 Os exemplos são inúmeros. As obras dos escritores da Geração do Peixe Frito constituem representações da vida simples de Belém, daquela que circula na periferia, como no Jurunas, em "Batuque", de Menezes (2015b); no Ver-o-Peso, por onde caminham o menino interiorano Alfredo e a cabocla Libânia, em "Belém do Grão-Pará", de Jurandir (1960); nos bairros do Umarizal e do Telégrafo, em "Ponte do Galo" (Jurandir, 1971). Há também a recriação de aspectos históricos, culturais e políticos da cidade pelos interstícios da "Gostosa Belém de outrora", de Ribeiro (2005); pela crônica, de relatos plenos de cenas e situações de diversas feiras em Belém, registrados em "Panela de barro", de Flores (1947); pelo tom modernizante e defensor da cultura nortista, nos manifestos e romances de Abguar Bastos; nas cenas memoriais - e biográficas - encontradas em cordéis de Lindolfo Mesquita, entre tantos outros.

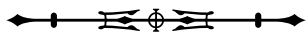


a memória assume papel importante nesse entrecruzar porque possibilita ao homem um reencontro consigo mesmo.

No entanto, na concepção deleuziana, essa memória admite dobras, as quais estão relacionadas à própria história, que a cada dia se dobra, formando curtas memórias, que se opõem ao esquecimento, mas que, ao longo do tempo, tornam-se absolutas, não se distinguindo mais do esquecimento. Essa memória não ocupa posição de prestígio em relação ao presente, ficando, portanto, esquecida até que desapareça ou até que seja lembrada e restaurada. Desse modo, conclui-se, a partir das ideias de Deleuze (1988), que o esquecimento é a impossibilidade de retorno e a memória, a necessidade de recomeço. A Academia do Peixe Frito (como memória) nos propiciou um recomeço, no sentido de ressignificação de elementos da história, do cotidiano e do sujeito, a partir de suas marcas no tempo, representadas pelas obras deixadas pelos escritores.

É nesse sentido que lugares e pequenos momentos do dia a dia, do vai-e-vem dos feirantes, dos estivadores, das pessoas da periferia paraense encontram espaço na literatura para falar de si também. Esse é o grande motivo da APF, visto que ela contribuiu para a formação de uma memória das classes populares na Amazônia, sobretudo em Belém, por meio da vasta produção literária e jornalística de seus membros. Dar voz aos excluídos pelas elites, fazê-los viver e significar por meio da palavra, num tempo em que não se falava nem se pensava em políticas públicas para a população mais carente, é uma posição política de engajamento muito consciente do escritor, já que, a partir dessa atitude, muitas vozes tradicionalmente silenciadas pela força da colonização - que ainda impera na Latinoamérica - (a do negro, do caboclo, do imigrante, do trabalhador, do morador da periferia, do candomblecista) não foram retiradas da cena social, e isso contribui para refrear as tentativas de apagamento desses sujeitos pela sociedade, pela historiografia, pelos poderes públicos.

Outros lugares não marcados no mapa também fazem parte da memória da APF e da fisiognomia da cidade delineada nos textos dos seus membros, por exemplo, a casa onde Bruno de Menezes passou a infância e a juventude (a casa da sua 'mãe preta' Maria Balbina Menezes), no bairro do Jurunas, que é outro lugar de significação na trilha ${ }^{17}$, sobretudo pelo sentido de negritude e pela consciência de classe que o Jurunas - desde seus primórdios, um bairro proletário, de negros, migrantes, descendentes de indígenas (Nunes; Costa, 2016) - infunde à sua obra.

Bruno de Menezes era de um espírito muito festeiro. A irmã do poeta, Maria de Lourdes Menezes (informação verbal) ${ }^{18}$, relatou, em entrevista, que, em épocas de comemoração, como nos festejos de São Benedito, no período natalino, nos aniversários, Bruno reunia familiares e amigos, alguns deles escritores, na casa da mãe, no Jurunas, e lá conversavam, comiam, bebiam, executavam as ladainhas - que a mãe dele muito apreciava (Reis, 2012). De todo modo, a presença do Jurunas é forte na obra do poeta líder do Grupo do Peixe Frito, sobretudo em "Batuque" (Menezes, 2015b), em que há alusões à Jaqueira, às comidas, ao samba, à marujada, às festas de santos, às práticas religiosas de matrizes africanas, aos bois-bumbás, às ladainhas, todos muito ligados à tradição jurunense (Reis, 2012; Rodrigues, 2008).

Além do Jurunas, o bairro de São Brás também marcou o Grupo do Peixe Frito. Lá, eram pontos de encontro o bar Paraense e o bar Pilsen, na avenida Independência (atual Magalhães Barata); e o bar Kean, no Largo de São Brás, em frente ao Mercado (Larêdo, 2012).

\footnotetext{
17 Rocha (1994 apud Reis, 2012) escreveu um ensaio biográfico sobre Bruno de Menezes e reportou-se a um lugar da infância do poeta chamado 'Estância coletiva (A) Jaqueira', que era um grande terreno no Jurunas. Além disso, segundo Reis (2012), a partir de informações obtidas por meio de entrevista realizada com a única irmã viva de Bruno de Menezes, Maria de Lourdes Menezes (à época, com noventa e seis anos), Bruno morou no Jurunas com a família (pais e irmãos) durante a infância e a juventude. Izabel Menezes, filha de Maria de Lourdes, informou que moravam na Roberto Camelier, n 425 (Reis, 2012).

18 Marcos Reis, em conversa informal com uma das autoras deste artigo, informou que, três meses depois dessa entrevista, D. Maria de Lourdes faleceu.
}

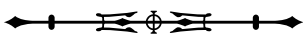


Os espaços verdes na Figura 1 representam os lugares menos frequentados, mas há registros da presença da APF na região da praça Siqueira Campos, conhecida como Praça do Relógio (área 4 na Figura 1), próximo ao porto de ancoragem dos barcos pesqueiros e ao porto do Açaí, onde havia o antigo necrotério de Belém. Bruno e Dalcídio, passantes, frequentadores ou contempladores do local, recriam aquele espaço em cenas de suas obras literárias.

Outro ponto era o City Club (ao lado do cinema Olímpia, área 5 na Figura 1), em frente à praça da República (Larêdo, 2012), onde os acadêmicos do Peixe Frito, boêmios que eram, passavam parte das noitadas, segundo nos revela Ribeiro (2005), em uma de suas crônicas publicada na obra "Gostosa Belém de outrora". Além dele, nas imediações, localizavam-se o Café Chic e o Café da Paz (área 5 na Figura 1), no terraço do Grande Hotel (antigo Hilton Hotel, hoje Princesa Louçã), que constituíam um ponto de encontro esporádico dos acadêmicos ${ }^{19}$. É importante reafirmar que os intelectuais elitizados preferiam o terraço do Grande Hotel; já os jovens acadêmicos da periferia de Belém elegeram o Ver-o-Peso como o espaço popular e de cultura para acolher suas reuniões.

\section{FISIOGNOMIA URBANA E MODERNIDADE}

Escrever a história significa dar às datas a sua fisionomia. (Benjamin, 2006, p. 518).

Walter Benjamin (1892-1940) buscou, em seus estudos sobre história literária e social da Alemanha do século XVII e da França do século XIX, apresentar uma abordagem fisiognômica para cada época estudada. De acordo com Bolle (2000), Benjamin explica sua ideia de 'fisiognomia' nas obras "Origem do drama barroco alemão" (Benjamin, 1984) e "Passagens parisienses" (Benjamin, 2006). Na primeira, ele defende que a construção da história se realiza por elementos convergentes na expressão de um rosto, ou melhor, de uma caveira; na segunda, busca formar 'o rosto da Modernidade' com uma concretude máxima, a partir de fragmentos de textos do século XIX, como de Honoré de Balzac, Allan Poe e Charles Baudelaire.

Conforme Guimarães (2016), desde a Antiguidade, o estudo da personalidade humana a partir dos traços exteriores (aparências) compõe as pesquisas de filósofos, cientistas e artistas. Tal estudo era denominado de fisiognomonia. Esse mesmo autor explica que a fisiognomonia é o "[...] estudo da fisionomia humana [semblante] como índice de conhecimento sobre as características abstratas e subjetivas a partir dos traços da cabeça e do rosto [...]" (Guimarães, 2016, p. 86).

Bolle (2000, p. 18) esclarece que 'fisiognomia' é um neologismo (de fisiognomonia) empregado "[...] para expressar um vaivém entre o objeto estudado, a 'fisionomia' da cidade e o olhar do 'fisiognomista' [...]". Acrescenta que é uma técnica de leitura da cultura e da sociedade apresentada por Benjamin, que remete a uma tradição fundamentada por Johann Caspar Lavater (1741-1801), fundador da fisiognomia moderna, o qual usava em seus estudos ilustrações dos rostos humanos para melhor produzir o conhecimento sobre os homens e a sociedade (Bolle, 2000).

Benjamin, por seu turno, passa a colecionar fragmentos de cultura, da produção artística, literária e intelectual, especialmente francesa, para, então, montar a fisiognomia da metrópole moderna, tomando como referências as cidades de Berlim e Paris, esta identificada como a 'capital do século XIX' (Bolle, 2000).

Por meio desses fragmentos urbanos, Benjamin constrói uma teoria da Modernidade, vinculada à questão das variáveis históricas da percepção humana, traçando um paralelo entre mentalidade burguesa e imagem da grande

\footnotetext{
19 Apesar de ter sido um dos primeiros locais de encontro da chamada Academia ao Ar Livre (Figueiredo, 2001), o espaço do Grande Hotel era requintado, frequentado pela elite belenense da primeira metade do século $X X$, por isso não vingou como local permanente de encontro, sobretudo quando a APF definiu seu lugar social de fala.
}

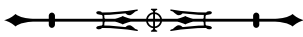


cidade. Para Benjamin, na Modernidade se estabelece um 'mercado de imagens' (Bolle, 2000) que interage com o imaginário coletivo. Nesse contexto, o papel do crítico é investigar o grau de consciência histórica das diferentes classes sociais, como operários e burgueses.

Segundo Bolle (2000, p. 20), Benjamin buscou, por meio da leitura fisiognômica da cidade ou da metrópole, ver "[...] o rosto da Modernidade 'de dentro', investigando traços da mentalidade burguesa e pequeno-burguesa, a mudança de padrões culturais, o imaginário social e político, $[\ldots]$ mediadores culturais e produtores de imagens $[\ldots]$ ". Nesse percurso, a produção literária foi fundamental, em virtude de sua qualidade mítica e mágica, de sua capacidade de plasmar a realidade social.

Gagnebin (2014) destaca que a teoria da Modernidade de Benjamin não corresponde a uma visão nostálgica do passado, uma vez que, na perspectiva do filósofo alemão, a Modernidade não se restringe às ideias de mera aceleração do tempo e à produção intensiva de mercadorias, com a consequente perda da tradição; pelo contrário, esse estágio de desenvolvimento histórico poderia contemplar também "[...] a invenção de novas formas de vida em comum [...], [capaz de] [...] transformar a técnica em instrumento de liberdade e felicidade [...]" (Gagnebin, 2014, p. 9-10). Benjamin compreende o tempo moderno partindo da análise de produções literárias e culturais da época, cuja apresentação do presente em imagens de caducidade reflete ou representa uma nova forma de produzir sentidos e experiências, de narrar a história.

Desse modo, a abordagem fisiognômica permite o surgimento de 'imagens dialéticas', que correspondem ao limiar e, ao mesmo tempo, a uma janela de leitura da História e do sujeito, num processo relacional em que há o corpo a corpo do sujeito histórico com a cidade. Bolle (2000) assinala que os fisiognomistas urbanos, o poeta, o escritor, o filósofo, o jornalista, oflâneur (ocioso sonhador), o passante observador buscam rastros, pistas, traços presentes no cotidiano urbano, com o objetivo de desmascarar feições e feitos, progresso e ruína da Modernidade.
Nesse sentido, pode-se dizer que os poetas e prosadores da Academia do Peixe Frito, apresentada anteriormente, foram fisiognomistas de sua época, porque perscrutaram o cotidiano da cidade de Belém, com gentes, histórias e memórias, de maneira singular, intrépida, transformadora e crítica, no intuito também de entender a Modernidade instaurada na Amazônia e seus efeitos.

Assim, os peixefritanos construíram textos-imagens de como percebiam a cidade e todos os seus componentes. Em muitos de seus poemas, seus romances, suas crônicas, revelam o quanto constituíam a cidade e o quanto por ela eram constituídos. A tentativa do grupo era construir textos que revelassem seu ideário de nação, marcadamente por meio do sentimento de pertença ao espaço, da identificação com o seu lugar de origem.

Nesse jogo de inter-relações, a presença deles na cidade manifesta-se de forma avassaladora em seus escritos, bem como a presença da cidade em cada um deles, em um processo de imbricamento e mútua identificação, como se pode entrever na ação dos acadêmicos do Peixe Frito, enquanto passam ou passeiam através da cidade, por ocasião das suas reuniões itinerantes e plurilocais, e nos textos literários produzidos por eles, entre os quais dois são analisados a seguir.

Bruno de Menezes e Dalcídio Jurandir foram dois desses escritores que se engajaram, direta ou indiretamente, na APF, que acreditavam na qualidade da literatura produzida no Pará e que tiveram grandes dificuldades para publicar. Em comum, tinham a origem pobre, a ascendência negra, o autodidatismo, a veia literária, o engajamento político e social e uma visão crítica acurada. Deles, analisam-se a seguir dois textos literários: do primeiro, o poema "Gente da estiva", em que o progresso da cidade de Belém custa a ruína (pessoal e social) do estivador; do segundo, trechos do romance "Belém do Grão-Pará", em que a cidade, tal qual um prisma sob o sol, traduz-se em imagens multifacetadas, fragmentárias, mas inteligíveis e coerentes.

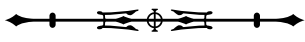




\section{“GENTE DA ESTIVA”, DE BRUNO DE MENEZES}

Bruno de Menezes (1893-1963), escritor, jornalista e ativista político, líder do grupo Academia do Peixe Frito, publicou a coletânea de poemas "Batuque" em 1931. Essa obra ressignifica a presença do negro no espaço amazônico, com tom de denúncia e notável qualidade estética (Nunes; Costa, 2016), pois apresenta o negro, trabalhador, morador da periferia, como protagonista social, subvertendo a ordem estabelecida pelos cânones literários tradicionais. Dessa obra faz parte o poema "Gente da estiva", que transcrevemos na íntegra, a seguir:

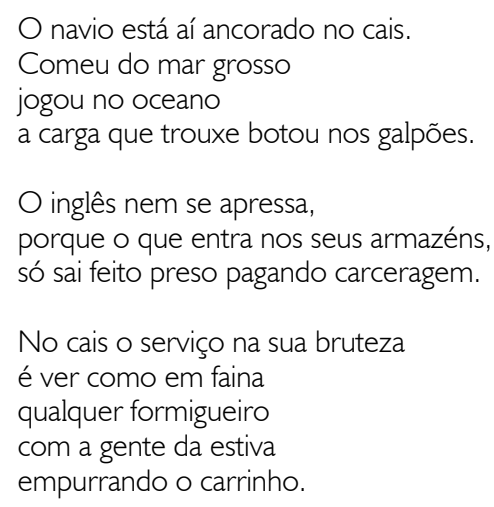

Fazendo lingadas

de sacos e fardos, trazendo caixotes barricas pranchões, que o braço de ferro dos altos guindastes arria de cima aos fundos porões.

A gente da estiva na lida afanosa parece escuras formigas troncudas.

$O$ ventre de ferro

de dia e de noite

vai sempre se enchendo daquilo que é vida.

E a gente da estiva ao voltar à casa, faminta esfalfada nem come daquilo que lhe andou nas mãos calejadas e humildes.

Repleta o navio o seu bojo de carga. E vozes de adeus sorrisos felizes

lembranças e beijos afagos abraços.

A campa retine.

A voz da sirene previne a partida.

A gente da estiva,

camisa suada estômago murcho,

como se fizesse trabalho forçado, recolhe o carrinho pra outras lingadas sem ter o direito até de fumar! (Menezes, 2015a, p. 67-68).

O poema encadeia imagens, as quais se traduzem em narrativa, a partir da descrição do espaço, do lugar, dos sons, das ações dos trabalhadores da estiva e da movimentação ao derredor do cais. $\bigcirc$ texto poético apresenta-nos a observação da cultura do cotidiano (muito cara a Benjamin, inclusive), que narra o comum, a rotina do dia a dia, à qual nem sempre atentamos, devido à sua fugaz banalidade. Dessa forma, percebe-se que Bruno de Menezes, assim como Benjamin, valoriza o fragmento: no poema, destaca-se a arraia-miúda, o 'trapilho social' (de Baudelaire), e vem à baila o protagonismo dos negros, dos trabalhadores braçais do mercado do Ver-o-Peso, da gente simples.

Em suas incursões pelos meandros da teoria do poema, Bosi (1977, p. 21) elabora uma pergunta intrigante: "O que é uma imagem no poema?, [ao que, em seguida, responde:] já não é, evidentemente, um ícone do objeto que se fixou na retina; nem um fantasma produzido na hora do devaneio: é uma palavra articulada". Candido (1996, p. 76) responde à pergunta feita por Bosi nos seguintes termos: "[A imagem no poema é] [...] o nome que damos a toda figuração de sentido que faz as palavras dizerem algo diferente de seu estrito valor semântico [...]"; é quando a linguagem proporciona a identificação entre realidades diversas, o que pode ocorrer por meio de uma comparação ou das palavras em sentido próprio. Ao discorrer sobre a 'imagem dialética', Benjamin (2006, p. 504) destaca que "Somente as imagens dialéticas são imagens autênticas (isto é: não arcaicas), e o lugar onde a

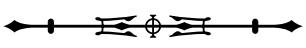


encontramos é a linguagem". Tal afirmação nos autoriza a compreender que, por meio de correspondências no plano simbólico, o escritor consegue reapresentar verdades e sentidos que a linguagem comum não traduz. Assim, no poema de Bruno de Menezes, a partir das suas projeções imagéticas, frutos da 'palavra articulada', narra-se a cidade, o cais próximo ao mercado do Ver-oPeso. É por meio dessa narrativa poética que se enforma uma fisiognomia do lugar e, por extensão, do eu. Desse modo, a imagem construída no/pelo poema é dialética (no sentido benjaminiano), uma vez que plasma a presença da cidade no sujeito poético, evidenciando a maneira como ele a lê e a reflete, já em síntese de si mesmo, pois ela (a cidade) faz parte do seu ser, do seu estar no mundo, e traduz a subjetividade do escritor.

A comparação da ação constante dos trabalhadores da estiva com um formigueiro ou com 'formigas troncudas' pode revelar a perspectiva do sujeito que olha a cidade, isto é, de onde ele olha: de longe, como se estivesse no mercado do Ver-o-Peso, observando o trabalho do estivador, negro, de retirar sacas do navio abarrotado e seguir com elas às costas, em fileira para o armazém das docas; ou olha de cima, como se fosse a própria cidade a observar os seus (informação verbal) ${ }^{20}$.

Além disso, essa comparação de homens com formigas alude à ideia do labor operário, do desafio de ser capaz de carregar mais do que o próprio peso e contribui para a formação de uma imagem. A propósito dessa questão, Candido (1996) associa a ideia de imagem no poema às relações de comparação que se estabelecem por meio da palavra para formar uma visualidade inusitada. Segundo ele, a imagem, parte essencial do verso, assim como a metáfora, as figuras e o símbolo, estabelece íntima ligação com a estrutura sonora do poema, contribuindo para a formação do todo significativo: "[...] a imagem cria o significado poético [...]" (Candido, 1996, p. 62).
$\mathrm{Na}$ esteira desse pensamento, percebemos a força significativa das imagens construídas em outros momentos do poema: em alguns trechos, como em "[...] a carga que trouxe botou nos galpões [...] trazendo caixotes barricas pranchões [...] o braço de ferro" (Menezes, 2015a, p. 67-68), considerando-se o contexto, aproximam e até confundem (no âmbito da significação denotativa e conotativa) o trabalho da máquina (os guindastes) com o do homem (a gente da estiva), remetendo a uma ideia marxista das relações de exploração do trabalho.

No entanto, isso não significa que a gente da estiva seja desenhada somente do ponto de vista da sua potencialidade no trabalho. Ao contrário: as metáforas da 'maquinização' humana compreendem uma crítica reflexiva acerca de como as subjetividades dessas pessoas são negligenciadas nas modernas relações de trabalho.

Nesse contexto, o próprio emprego do termo 'gente', na expressão 'gente da estiva', que intitula o texto poético, apesar de agregar a ideia de coletivização, de generalização, reconstrói-se para individualizar o ser, para nomear um sujeito que volta para casa, que tem família, que sente fome, que sofre, que precisa de momentos de lazer e de descanso. $\bigcirc$ último verso do poema é desvelador: "[...] sem ter o direito até de fumar!" (Menezes, 2015a, p. 68), em que o eu lírico se consterna com a falta de possibilidade de momentos de ócio ou devaneio para a gente da estiva, numa época em que o ato de fumar era considerado socialmente positivo e necessário ao homem.

Por meio dessas cenas, construímos uma expressão, uma aparência da cidade, isto é, a sua fisiognomia, sempre marcada historicamente pela subjetividade e pela cosmovisão do leitor. No seminal ensaio "A metrópole e a vida mental", Simmel (1973, p. 21) assinala que "[...] $\bigcirc$ âmbito da pessoa é antes constituído pela soma de efeitos que emana dela temporal e espacialmente. Da mesma maneira, uma cidade consiste em seus efeitos totais, que

${ }^{20}$ Essa leitura de que a cidade pode ser aquela que traduz o sentimento lírico no poema foi sugerida pelo professor José Maria Damasceno Ferreira, em conversa informal com duas das autoras desta pesquisa.

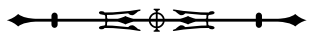


se estendem para além de seus limites imediatos [...]". Nesse contexto, o processo de visibilidade homem-cidade plasmado no/pelo poema de Bruno de Menezes evoca aspectos que vão além da superfície, das aparências das realidades interior e exterior, entrelaçando percepções, experiências e narrativas intercambiantes, que não se esgotam com o dia vivido, com a 'lida afanosa'.

Ao estudar a importância da imagem na construção do poema, Bosi (1977, p. 15-16) defende uma visão histórica, contextualizada, e não estanque, da imagem: "A imagem nunca é um 'elemento': tem um passado que a constituiu; e um presente que a mantém viva e que permite a sua recorrência [...]”. Essa reflexão remete a Benjamin (2006, p. 518), quando afirma que "A história se decompõe em imagens, não em histórias [...]”, uma vez que só é possível decifrar as verdades históricas nas tensões entre o 'ocorrido' e o 'agora' da leitura evocada pelo jogo verbo-imagético.

No poema, as imagens dos guindastes, dos porões, das lingadas no antigo cais do porto retomam a função original do que, na atualidade, tem também valor simbólico, já que parte do espaço do cais dos navios de carga e alguns objetos foram ressignificados e passaram a compor o centro turístico de Belém: é possível perceber, por exemplo, que alguns dos guindastes se tornaram enfeites ou objetos históricos em exposição na Estação das Docas, atualmente um espaço de lazer e visitação, nas proximidades do Ver-o-Peso. Mas, próximo dali, o trabalho da estiva continua.

Desse modo, a fisionomia da cidade construída em "Gente da estiva" evoca o mercado do Ver-o-Peso como expressão do trabalho, da vida/lida, com a qual ele se identifica. O poema de Bruno revela a voz de alguém que está ali frequentemente, que é íntimo observador daquele espaço. Assim, cria-se uma fisiognomia do lugar intrinsecamente ligada (isto é, como parte dos seus traços característicos) ao trabalhador, ao homem comum.

Isso não seria possível sem um conhecimento profundo e crítico do lugar em que se habita, sem o desenho de uma mundividência que perceba o outro pobre, trabalhador braçal, como integrante do lugar e indispensável, porque importante, para a constituição de uma fisiognomia que, por vezes, é escondida propositalmente: a de uma Belém que se ergueu com a força do trabalho do homem comum, numa relação cíclica de progresso e ruína, nos termos benjaminianos.

A fisiognomia da cidade é um dos elementos que ajudam a definir identidades, porque ela fala do eu e identifica-o como sujeito histórico:

\section{Benjamin e Baudelaire, cada um à sua maneira, tentaram flagrar esse momento em que o sujeito se inteira da fisiognomia da cidade e ao mesmo tempo de si mesmo, em que rosto e corpo se assemelham mimeticamente à cidade que ele habita, como se ela fosse a constelação que define sua identidade, a estrela de sua vida inteira. (Bolle, 2000, p. 43-44)}

Assim, de acordo com a perspectiva benjaminiana, traduzida por Bolle (2000), o sujeito constitui-se simultaneamente dessas duas fisiognomias (da cidade e de si mesmo). Ele se reconhece como parte da cidade, ao mesmo tempo em que percebe que a cidade está nele, visto que ambos se refletem: é o eu na cidade e a cidade em mim, é a imagem de confluência, da identificação.

\section{"BELÉM DO GRÃO-PARÁ", DE DALCÍDIO JURANDIR}

Dalcídio Jurandir ${ }^{21}$ (1909-1979) foi escritor, jornalista e funcionário público. Paraense, partícipe da Geração do

\footnotetext{
${ }^{21}$ Consoante às ideias de Furtado (2010), Dalcídio começou a escrever as obras do ciclo do Extremo Norte no final dos anos 1930 e sua técnica de escrita sofreu influências positivas da renovação estética dos anos 1920 e dos subsequentes, o que demonstra que ele era um escritor alinhado aos bons literatos da sua época. Acrescentamos, sem receio de especulação, que a forte presença da APF na vida literária de Dalcídio Jurandir teve parte para que ele apreendesse esse espírito do tempo e o refletisse tão distintamente em sua obra.
}

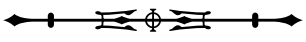


Peixe Frito, sua obra literária é considerada vasta: escreveu onze romances e muitos poemas ${ }^{22}$, alguns esparsos, que, de vez em quando, pululam, redescobertos, e crônicas que, em sua quase totalidade, narram lugares (físicos, históricos, ideológicos) subalternizados no interior do Pará e na cidade de Belém. Entre essa produção artística, destaca-se "Belém do Grão-Pará"23 (BGP), quarto romance do Ciclo do Extremo Norte, publicado pela primeira vez no Brasil, pela Martins, de São Paulo, em 1960.

"Belém do Grão-Pará" segue a tradição do romance urbano moderno, em que o humano se dilui em contato com os grandes centros, na ideia de uma multidão multiforme 'tocada' pela experiência com as máquinas e outras tecnologias. No caso de BGP, o bonde elétrico (referido no final deste artigo), o trem, o cinema e a luz elétrica são temáticas recorrentes que marcam a vida de Alfredo e seus companheiros na cidade grande.

Nessa obra, Dalcídio Jurandir ressignifica a Belém dos anos 1920 a partir da visão do menino Alfredo, que, vindo de Cachoeira (no Marajó), chega a Belém para superar a precariedade da educação marajoara, e enseja continuar seus estudos na capital do Pará. O garoto passa a morar, na condição de agregado, com a família Alcântara ${ }^{24}$, falida devido à decadência do governo lemista e da economia da borracha. Entre descobertas e desencantos, Alfredo constitui uma fisiognomia da cidade a partir de sua vivência, porque procura decifrá-la, como efígie de si mesmo, mas não sem a ajuda de personagens instigantes, como a cabocla Libânia, muito íntima da cidade, acostumada a transitar a pé do bairro de Nazaré até o mercado do Vero-Peso. Na sequência, apresentamos dois excertos desse romance para discutir como o anverso da cidade constitui o reverso (interior) do sujeito histórico.

Neste trecho de "Belém do Grão-Pará", Libânia (a cabocla criada dos Alcântara) leva Alfredo, pela primeira vez, ao Ver-o-Peso:

Viva maré de março visitando o Mercado de Ferro, lojas e botequins, refletindo junto ao balcão os violões desencordoados nas prateleiras. Os bondes, ao fazer a curva no trecho inundado, navegavam. As canoas no porto veleiro, em cima da enchente, ao nível da rua, de velas içadas, pareciam prontas a velejar cidade adentro, amarrando os seus cabos nas torres do Carmo, da Sé, de Santo Alexandre e nas samaumeiras do arraial de Nazaré. Libânia corria então para ver: os bons barcos, panos cor de telha, cobriam o Ver-o-Peso com um telhado de velas. Libânia apontava as montarias cheias de potes queimados como a sua face, e bilhas de barro e as andorinhas curiosas dos mastros, das proas com peixe assando e as mãos de milho verde que descarregavam. [...] Voltava-se agora para os cestos, fogareiros de barro, bichos, cachimbos, 'ah, este-um, aqui, eu fumava'. O gosto de provar de todas as farinhas ali expostas nos paneiros em plena calçada não atingida ainda pela maré. Pôsse a provar desta, daquela, a amarelinha, a bem torrada, fingindo enfado, competência, exigente no escolher. Cada melancia, aquele ananás, uns muçuãs que deviam estar gordinhos, a tracajá virada, Deus! $\bigcirc$ doente da pele bebendo mingau no quiosque. Um velhusco, suada a camisa colando nas costas, a bagana na boca, conferia pules de bicho. [...] Depois, aquela rapariga de perna inchada-inchada, no rosto um rouge como uma queimadura. A carroça fazia mudança, atravancando a rua. Um papagaio foge da bagagem. [...]. Ela [Libânia] volvia à Gentil como se viesse do sítio, com o embrulho das raízes, filha daqueles barcos, nascida entre panelas de barro, ovas de tainha e cofos de caranguejos. (Jurandir, 2016, p. 76-80).

22 "Poemas impetuosos" é a coletânea que reúne, pela primeira vez em livro, os poemas de Dalcídio Jurandir. O trabalho foi organizado por Paulo Nunes, no projeto "Negritude e literatura", ligado ao PPGCLC, da UNAMA, e publicado em convênio com a editora PakaTatu e com a Casa de Cultura Dalcídio Jurandir, em 2011 (Jurandir, 2011).

${ }^{23}$ Esse romance teve duas edições em Portugal, pela editora Europa-América, na série "Grandes autores contemporâneos", em 1982 (Nunes, 2007).

${ }^{24}$ É curioso perceber-se que o nominativo familiar Alcântara, etimologicamente, significa 'ponte'; as pontes, como se sabe, proporcionam a passagem de um lugar a outro. Poder-se-ia aqui falar das passagens benjaminianas, mas isso proporcionaria um outro estudo; ficamos, assim, com a ideia de transporte, passagem, experiência de mudança e migração de Alfredo de Cachoeira a Belém, processo no qual a família Alcântara tem um papel fundamental para os descortinamentos de dramas humanos, individuais e sociais, no romance (Nunes, 2007; Pereira, 2014).

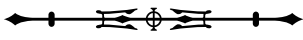


Nessa passagem, o espaço do mercado do Vero-Peso, em Belém, é narrado de forma dinâmica, com a vivacidade de quem naturalmente observa a movimentação do mercado; de quem é conhecedor das minúcias do dia a dia e dos detalhes característicos daquele ambiente, com o qual as personagens interagem de forma viva, afetuosa e afetiva. Tal descrição não é perpassada por um olhar exótico ${ }^{25}$ (de que costumeiramente o mercado-feira é vítima), também não traz o ranço do superficialismo, o olhar apressado, e por vezes parcial, do turista, que não tem a vivência cotidiana daquele espaço, que compreende uma espécie de entrelugar entre a floresta e a cidade. Dessa forma, não são imagens espetacularizadas ou estandardizadas, elas mostram o ordinário, o corriqueiro, o que é próprio de uma fisionomia do Ver-o-Peso, que está incrustada no narrador, como uma tatuagem ${ }^{26}$.

Nesse contexto, a expressão do lugar é marcada pelo filtro bastante singular (do narrador e das personagens) que estilhaça o espelho da cidade diante do leitor e, ao mesmo tempo, reúne os fragmentos numa narrativa intensamente visual, composta por uma pluralidade de ações simultâneas, ágeis, por imagens que, num plano comum, delineiam o 'pano de fundo', mas, no plano da narrativa, constituem o principal da cena, conduzida por um narrador quase cinematográfico. No contexto da obra de Dalcídio Jurandir, percebemos a imagem associada ao poder de expansão do discurso, para dar fluidez, dinamismo à cena poética ${ }^{27}$. Trata-se de artimanhas em que o autor de identidade social, Dalcídio Jurandir, industria, com perspicácia e eficiência, o autor da diegese, qual seja, o narrador.
O campo semântico do excerto é atravessado por expressões da cultura local; significantes como Mercado de Ferro, canoas, torres da Sé, barcos, Ver-o-Peso, paneiros de farinha, ananás, mingau no quiosque, embrulhos das raízes, panelas de barro etc. formam imagens e expressões amazônidas, que denotam pertencimento do narrador, tanto quanto das personagens, ao universo do Ver-o-Peso.

Libânia, por exemplo, caminha livre pela feira e demonstra muita experiência e perspicácia no escolher, no provar, no admirar, no olhar a paisagem de velas de embarcações, nos cheiros que sente por onde passa, na observação dos tipos humanos com os quais se depara. Enfim, a menina Libânia movimenta todos os sentidos ao experienciar a feira e apresentá-la a Alfredo. O narrador capta esse aspecto e o lança aos olhos do leitor, que constrói a imagem de uma personagem concatenada ao espaço em que circula habilmente, como se ela fosse parte física dele, como se sujeito e cidade fossem indissociáveis, um nascido do outro, conforme se expressa ao final do trecho: a imagem da menina-moça filha dos barcos, nascida entre panelas de barro, pescado e caranguejo. Assim, chama a atenção a forma enunciativa do texto, que transmite cumplicidade entre o eu enunciador, as personagens e o espaço narrado, como se a imagem especular da cidade refletisse a memória do eu, a sua identidade, enfim, a sua própria fisiognomia, unindo-as, (con)fundindo-as, conforme a teoria benjaminiana acerca da imagem na cultura do cotidiano.

Em outro excerto, Alfredo volta ao mercado, dessa vez acompanhando o Sr. Virgílio Alcântara, figura masculina da família com a qual o menino morava desde

25 Observe-se a etimologia da palavra. Segundo o "Dicionário Houaiss da Língua Portuguesa”, "exótico, original do grego eksótikós, ê,on, significa 'de fora, exterior', der. do adv. éksó 'fora', pelo lat. exoticus, a,um, 'estranho, estrangeiro, peregrino, que vem de fora', prov. por infl. do fr. exotique" (Houaiss, 2009, p. 1552): "que pertence, que é relativo a um país estrangeiro" (Houaiss, 2009, p. 1690); "que foi importado de país estrangeiro, em particular de regiões quentes da Terra" (Houaiss, 2009, p. 1690).

26 Note-se que o narrador de "Belém do Grão-Pará" narra a partir de um pacto emocional, espécie de adesão aos sentimentos das personagens envolvidas na cena; assim ocorre com Alfredo, a partir de sua chegada à cidade, assim também com Libânia, nas cenas narradas e noutras passagens do romance.

27 Bosi (1977) trata dessa relação entre imagem e construção discursiva. $\bigcirc$ autor articula o pensamento de que a ideia expressa por meio da imagem é extremamente poderosa porque é fonte inesgotável de produção de sentidos.

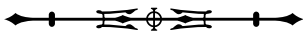


sua chegada a Belém, família na qual ele foi incorporado como agregado. A experiência que ele tem nessa outra visita ao Ver-o-Peso é diferente da primeira, pois visualiza outra cidade, apesar de estar no mesmo lugar onde anteriormente esteve:

No domingo seguinte, seu Alcântara levou ele [Alfredo] ao Ver-o-Peso. [...] Seu Alcântara, como um administrador do Mercado, tinha uma visível delícia em escolher demoradamente o melhor peso da carne dominical, a melhor penca da banana na quitanda e as boas alfaces no verdureiro. Ao chegarem ao Ver-o-Peso, lhe apeteceu uma tainha fresca, e Alfredo via, então, uma nova cidade, agora sem Libânia, meio bruta, que lhe pedia dinheiro em troca de peixes, carnes, frutas e verduras, panelas de mingau, prateleiras de cheiro, dentes de boto, línguas de pirarucu, cascas e raízes, defumações e ninhos de gavião-coré contra mau olhado, quebranto, contra qualquer gênero de infelicidade. Seu Alcântara, com o seu conhecimento meticuloso de mercados, conversava com este e aquele peixeiro, examina aqui a barriga da tainha, ali a gurijuba, peixe grande de comer homem. Adiante o monte de pratiqueiras que lembravam a Alfredo os peixinhos nadando embaixo do chalé e em Belém, na panela de barro, nadando no tucupi. (Jurandir, 2016, p. 76-97).

Em ambos os trechos de "Belém do Grão-Pará", percebemos uma descrição ininterrupta (quase frenética) das ações sobrepostas, dos recortes e das montagens das imagens, da movimentação das personagens. Essa estratégia narrativa remete à concepção benjaminiana de superposição de imagens, conforme comenta Bolle (2000), em escrito sobre o filósofo: "De Baudelaire, ele aprendeu a ver a cidade como um corpo humano e a usar a técnica de superposição que faz com que, miticamente, a percepção da cidade e a do próprio corpo se confundam" (Bolle, 2000, p. 43).

Por isso, evidencia-se o fato de o narrador ser muito íntimo do lugar, quase como se ele falasse dele mesmo, como se promovesse uma autonarração. Trata-se, assim, de uma visão expressiva, extremamente vivaz, muito bem delineada do espaço do mercado do Ver-o-Peso, não só porque cria uma narrativa verossimilhante, mas porque recria discursivamente o espaço do mercado a partir de múltiplas facetas, como imagem especular. Em estudo sobre a literatura e o cinema da Amazônia, Pinho (2015, p. 81), fundamentado nas teorias de Clifford Geertz e Walter Benjamin, afirma que "Dalcídio busca na história, na experiência pessoal, na experiência discursiva sobre a cidade, um passado que pode não ter ocorrido tal como ele narra". Nesse sentido, a estética dalcidiana pode também evocar o passado não apenas como mera lembrança, mas como possibilidade de compreensão e ressignificação da história.

Dessa vez, levado por seu Alcântara, Alfredo se depara com um Ver-o-Peso diferente daquele que vivenciou com Libânia. O homem negocia, escolhe, examina, conversa e compra, tudo muito meticuloso, numa cidade embrutecida. Mas o narrador nos anuncia que $\mathrm{o}$ garoto se desvencilha disso, porque as imagens que seguem remetem a uma Belém de crenças em chás de raízes e amuletos contra toda sorte de infelicidades, aspecto que se sobressai na narrativa e anuncia a interação entre modernidade e tradição. Além disso, por meio da memória, o menino busca pontos de identificação entre aquele seu novo lugar e a Cachoeira deixada para trás, com os peixes que nadavam embaixo do chalé.

Nessa perspectiva, Dalcídio lança mão de procedimentos narrativos, como a ironia, para reacender no leitor dúvidas sobre as verdades de uma certa visão de história, que celebra as elites. $\bigcirc$ aprendizado e a sensibilidade para o social, que Dalcídio Jurandir aprendeu com os companheiros da Academia do Peixe Frito, na mocidade, e com os companheiros do Partido Comunista, na maturidade, fizeram-no optar pelas tramas do enredo em movimento centrípeto, em que as margens se aproximam do centro da trama. Em Dalcídio Jurandir, como em Bruno de Menezes e demais peixefritanos, expressam-se prioritariamente os sujeitos das periferias, das margens da cidade e de toda a Amazônia.

Nesse excerto, há uma superposição de imagens. Estas são embaralhadas, remexidas, coladas e, ainda assim, significam, devido à harmonização do que comunicam. E mais ainda: a imagem do todo se constitui a partir de 
fragmentos, detalhes que a outros olhares, diferentes do narrador que presencia as cenas, passariam despercebidos, tal a sua aparente insignificância.

Essa visão de valorização do pequeno, do fragmento, do insignificante, assemelha-se à de Benjamin (2006), uma vez que ele lança a esses materiais desprestigiados historicamente um olhar minucioso, de reconhecimento de sua importância para a compreensão humana da/na cultura. Com os 'rastros' da realidade social e subjetiva, Dalcídio Jurandir constrói, em "Belém do Grão-Pará”, "[...] uma re(a)presentação da história, [manejando] experiências distintas, deslocadas no espaço e no tempo, mas que são reagrupadas na narrativa e demarcam vivências diferentes [...]" (Pinho, 2015, p. 79).

Nesse último trecho da narrativa dalcidiana em tela, há dois fragmentos muito sintomáticos: imagens do Vero-Peso e da sua Cachoeira recordada, uma remetendo à outra, acionadas a partir de fragmentos de memória, que são trazidos à tona pelo narrador e abruptamente, mas também sutilmente, lançados diante do leitor, que os reúne e, assim, pode ressignificá-los.

Desse modo, a fisionomia que o eu do narrador constrói da cidade confunde-se com a fisionomia dele próprio, porque ela constitui uma identificação com o lugar, mediada pela memória, revelando uma identidade cabocla, amazônida, de alguém que vivencia o cotidiano de Belém, que está, portanto, em Belém não apenas a passeio, mas usa essa experiência como aprendizado. Nesse sentido é que se pode ver a narrativa de Alfredo em Belém como expressão de um romance de formação da personagem. Estar em Belém é aprender com Belém e suas gentes, acumulando sabedoria e vivências para toda a vida. Assim, é ele mesmo esse sujeito das imagens tra(n)çadas nas narrativas, em que estética e experiência se confluem no jogo verbo-imagético.

A cidade de Alfredo, que conflui da leitura do romance "Belém do Grão-Pará", configura uma fisionomia singular; singularidade que Dalcídio Jurandir soube pintar com tintas bastante originais. Dalcídio é um autor que nos faz, a cada página, redescobrir, em que pese toda a força ficcional de sua narrativa, uma cidade pulsante, expressiva, única. Como diz o narrador, no excerto do passeio de Alfredo e dona Amélia no bonde elétrico: "A cidade [de Belém] balançava ainda. Ou estava [Alfredo] tonto com os cheiros de Belém?" (Jurandir, 2004, p. 94). Essa passagem do romance e as duas outras sobre o Vero-Peso aqui apresentadas mostram uma reconstrução do espaço citadino refletida na subjetividade da personagem e, por isso, constroem uma fisiognomia do lugar. A Belém de Dalcídio Jurandir, ressignificada na experiência de Alfredo, afinal, deixa-nos tontos, tontos e encantados.

\section{CONCLUSÃO}

No estudo realizado, investigamos as redes de significação entre a Academia do Peixe Frito e a fisiognomia da cidade de Belém do Pará, a partir da observação analítica de textos literários dos acadêmicos do Peixe Frito e dos lugares que os jovens literatos e jornalistas paraenses costumavam frequentar entre 1920 e 1950, para beber, conversar amenidades, discutir literatura e difundir seus pensamentos. Ao fim do percurso, percebemos que, desse movimento, resultou uma produção estética na qual a cidade se reflete ao mesmo tempo em que reflete as experiências do sujeito histórico.

Como foi demonstrado, a atuação da APF desvelou ligações intrínsecas da produção intelectual com o lugar de origem dos peixefritanos: o lugar-cidade de suas experiências e existências os construía como sujeitos do seu tempo. Nesse sentido, ele (o lugar) constitui a APF e forma a fisiognomia da cidade representada pelos escritores.

Para a realização deste estudo, a categoria 'fisiognomia' urbana, na perspectiva de Benjamin (2006), possibilitou-nos reconhecer os poetas e prosadores que compunham a Academia do Peixe Frito como fisiognomistas de sua época, porque recriaram verboimageticamente o cotidiano da cidade de Belém no período da modernidade amazônica.

Os textos literários aqui analisados apontam para produções estéticas nas quais a cidade é o lugar onde

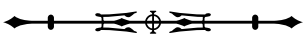


os escritores atuam como caminhantes observadores a perscrutarem a cidade, a redesenharem sua fisionomia, por meio da confluência de imagens do cotidiano e do imaginário social estabelecido. Na perspectiva benjaminiana apresentada, a linguagem constitui-se como fonte de expressão, na qual prevalece a capacidade imaginativa e simbólica no ato de leitura e a representação dos objetos e do mundo. Dessa maneira, a produção literária da APF constitui uma experiência na linguagem, uma forma de escrita do mundo sensível, da vida cotidiana fragmentária da cidade de Belém e de seus sujeitos, sobretudo daqueles que estão à margem da cidade e habitam as fisionomias periféricas do mapa de Belém, e são desvelados pela escrita.

Candido (1996), na obra "O estudo analítico do poema", cujos trechos atravessaram esta discussão, elabora uma afirmação acerca do escritor e das suas relações com a imagem. Vale a pena repetir aqui suas palavras, porque elas traduzem o sentimento poético-imagético percebido em Bruno de Menezes e Dalcídio Jurandir:

[O poeta tem a] capacidade de perceber vivamente e intensamente com os sentidos; logo, de apreender com força as coisas e o espetáculo do mundo. Daí o sentimento das analogias, a capacidade de correlacionar, de substituir e de transpor, que está na base da formação das imagens. Há poetas que denotam mais claramente do que outros esta capacidade, porque manifestam os aspectos exteriores da sua sensorialidade: senso das cores, dos ritmos, do tacto, do gosto. Noutros, tais aspectos aparecem difusos ou sublimados, mas em todos estão presentes quando analisamos a contextura da sua obra. (Candido, 1996, p. 65).

Dalcídio e Bruno, indubitavelmente, são desses poetas do primeiro grupo referido pelo autor: sua escrita tem força poética, tem imagens em movimento, tem as experiências sensoriais entremeadas e aguçadas, tem a experiência imagética enraizada no corpopalavra (assim mesmo, tudo junto, porque neles esses dois elementos são inseparáveis). E tudo isso fica patente quando lemos a sua obra, quando sentimos sua estética ligada à sua experiência de sujeitos históricos.
Por meio da poíesis, esses escritores peixefritanos recolheram fragmentos, detritos, farrapos, enfim, rastros de uma realidade social amazônica e os tomaram como fagulhas para iluminar uma compreensão crítica do seu presente em diálogo refletido com o passado, com a tradição. Na luta diária pela sobrevivência no espaço urbano belenense, tantas 'gentes da estiva', tantas famílias trabalhadoras, tantos 'Alfredos' e 'Libânias' resistiram e deixaram pegadas de suas existências no olhar atento dos caminhantes peixefritanos, em sua experiência na linguagem: a literatura.

\section{REFERÊNCIAS}

ADORNO, Theodor W. Notas de literatura I. Tradução: Jorge de Almeida. São Paulo: Duas Cidades: Editora 34, 2003.

BENJAMIN, Walter. Passagens parisienses. In: BENJAMIN, Walter. Passagens. Belo Horizonte: UFMG; São Paulo: Imprensa Oficial do Estado de São Paulo, 2006. p. 901-963.

BENJAMIN, Walter. Origem do drama barroco alemão. Tradução: Sérgio Paulo Rouanet. São Paulo: Brasiliense, 1984.

BOLLE, Willi. Fisiognomia da metrópole moderna: representação da história em Walter Benjamin. 2. ed. São Paulo: Edusp, 2000.

BORGES, Tatiana Carepa Roffé. Do Largo das Mercês à Praça Visconde do Rio Branco: um estudo de gestão do patrimônio histórico em Belém do Pará (1941-2011). 2013. Dissertação (Mestrado em Arquitetura e Urbanismo) - Universidade Federal do Pará, Belém, 2013.

BOSI, Alfredo. História concisa da literatura brasileira. 41. ed. São Paulo: Cultrix, 2003.

BOSI, Alfredo. O ser e o tempo da poesia. São Paulo: Cultrix: EDUSP, 1977.

BRITO, Lenora Menezes de. Academia do Peixe Frito. In: GALLINDO, Afonso. O Negro no Pará: cinco décadas depois. Direção: Afonso Gallindo. Belém: Instituto de Artes do Pará, 2005. 1 DVD-R (38 min), color.

CANDIDO, Antonio. O estudo analítico do poema. 3. ed. São Paulo: Humanitas Publicações, 1996.

CASTRO, Maria das Neves Rocha de. Memórias de uma velha cidade: a representação histórico-social de Belém pós-Belle Époque em crônicas de De Campos Ribeiro. 2011. Dissertação (Mestrado em Letras Estudos Literários) - Instituto de Letras e Comunicação, Universidade Federal do Pará, Belém, 2011.

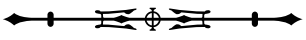


COELHO, Marinilce Oliveira. Memórias literárias de Belém do Pará: o Grupo dos Novos, 1946-1952. 2003. Tese (Doutorado em Teoria e História Literária) - Instituto de Estudos da Linguagem, Universidade Estadual de Campinas, Campinas, 2003.

COSTA, Antônio Mauricio Dias da. Festa de santo na cidade: notas sobre uma pesquisa etnográfica na periferia de Belém, Pará, Brasil. Boletim do Museu Paraense Emílio Goeldi. Ciências Humanas, Belém, v. 6, n. 1, p. 197-216, jan./abr. 2011. DOI: http://dx.doi. org/10.1590/S1981-81222011000100012.

DELEUZE, Gilles. Foucault. Tradução: Claudia Sant'Anna Martins. São Paulo: Brasiliense, 1988.

FIGUEIREDO, Aldrin Moura de. De pincéis e letras: os manifestos literários e visuais no modernismo amazônico na década de 1920. Revista Territórios e Fronteiras, Cuiabá, v. 9, n. 2, p. 130-155, jul./dez. 2016.

FIGUEIREDO, Aldrin Moura de. Eternos modernos: uma história social da arte e da literatura na Amazônia, 1908-1929. 2001. Tese (Doutorado em História Social) - Instituto de Filosofia e Ciências Humanas, Universidade Estadual de Campinas, Campinas, 2001.

FLORES, Jaques. Panela de barro. Rio de Janeiro: Andersen Editores, 1947. (Crônicas, ensaios, fantasias).

FURTADO, Marli Tereza. Universo derruído e corrosão do herói em Dalcídio Jurandir. Campinas: Mercado de Letras, 2010.

GAGNEBIN, Jeanne Marie. Limiar, aura e rememoração: ensaios sobre Walter Benjamin. São Paulo: Editora 34, 2014.

GUIMARÃES, Pedro Maciel. No rosto, lê-se o homem: a fisiognomonia no cinema. Significação: revista de cultura audiovisual, São Paulo, v. 43, n. 46, p. 85-105, 2016.

HOUAISS, Antônio. Dicionário Houaiss da Língua Portuguesa. [São Paulo]: Objetiva, 2009. 1 CD-ROM.

INOJOSA, Joaquim. Os Andrades e outros aspectos do Modernismo. Rio de Janeiro: Civilização Brasileira; Brasília: INL, 1975.

JURANDIR, Dalcídio. Belém do Grão-Pará. 4. ed. Belém: Marques, 2016.

JURANDIR, Dalcídio. Poemas impetuosos ou o tempo é o do sempre escoa. Belém: Paka-Tatu, 2011.

JURANDIR, Dalcídio. Belém do Grão-Pará. Belém: EDUFPA; Rio de Janeiro: Casa de Rui Barbosa, 2004.

JURANDIR, Dalcídio. Ponte do Galo. São Paulo: Martins, 1971.

JURANDIR, Dalcídio. Belém do Grão-Pará. São Paulo: Martins, 1960.
LARÊDO, Salomão. Geração Peixe Frito ou Academia do Peixe Frito. Belém: [s. n.], 2012.

MENEZES, Bruno de. Gente da estiva. In: MENEZES, Bruno de. Batuque. 8. ed. Belém: GTR, 2015a. p. 67-68.

MENEZES, Bruno de. Batuque. 8. ed. Belém: GTR, $2015 \mathrm{~b}$.

MENEZES, Bruno de. Bailado lunar. In: MENEZES, Bruno de. Obras completas de Bruno de Menezes: obra poética. Belém: Secretaria de Estado da Cultura, 1993. v. 1, p. 77. (Lendo o Pará, n. 14). Disponível em: https://issuu.com/ufpadoispontozero/ docs/obras_completas_de_bruno_de_menezes. Acesso em: 18 mar. 2019

NARRAMAZÔNIA. $7^{\text {a }}$ Trilha literária da Academia do Peixe Frito leva estudantes aos complexos Feliz Lusitânia e Ver-o-Peso. Belém, 2017. Disponível em: https://narramazonia.wordpress.com/2017/11/20/7atrilha-literaria-da-academia-do-peixe-frito/. Acesso em: 17 jan. 2018.

NUNES, Paulo Jorge Martins; COSTA, Vânia Maria Torres. Academia do Peixe Frito: diálogos e intersecções entre Literatura, Jornalismo e Ciências Sociais na Amazônia do século XX. In: ENCONTRO ANUAL DA ANPOCS, 40., 2016, Caxambu, Minas Gerais, 2016. Anais [...]. Caxambu, MG: ANPOCS, 2016. p. 1-26. Disponível em: http://www.anpocs.com/index.php/papers-40-encontro/st-10/st028/10533-academia-do-peixe-frito-dialogos-e-interseccoes-entreliteratura-jornalismo-e-ciencias-sociais-na-amazonia-do-seculo-xx/ file. Acesso em: 10 jan. 2018.

NUNES, Paulo Jorge Martins. Útero de areia, um estudo do romance 'Belém do Grão-Pará', de Dalcídio Jurandir. 2007. Tese (Doutorado em Literaturas de Língua Portuguesa) - Pontifícia Universidade Católica de Minas Gerais, Belo Horizonte, 2007.

PACHECO, Terezinha de Jesus Dias. Bruno de Menezes e o modernismo no Pará. Revista Em Tese, Belo Horizonte, v. 6, p. 165-172, ago. 2003. DOI: http://dx.doi.org/10.17851/19820739.6.0.165-172

PEREIRA, Carla Soares. Varadouros e silêncios: (des)caminhos da borracha em 'Belém do Grão-Pará', de Dalcídio Jurandir, e 'Seringal', de Miguel Ferrante. 2014. Dissertação (Mestrado em Comunicação, Linguagens e Cultura) - Universidade da Amazônia, Belém, 2014.

PINHO, Relivaldo. Antropologia e filosofia: experiência e estética no cinema e na literatura da Amazônia. Belém: EdUFPA, 2015.

REIS, Marcos Valério Lima. Entre poéticas e batuques: trajetórias de Bruno de Menezes. 2012. Dissertação (Mestrado em Comunicação, Linguagens e Cultura) - Universidade da Amazônia, Belém, 2012.

RIBEIRO, De Campos. Gostosa Belém de outrora. Belém: SECULT, 2005.

RIBEIRO, De Campos. Graça Aranha e o modernismo no Pará Belém: Conselho Estadual de Cultura, 1973.

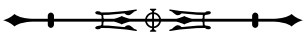


ROCHA, Alonso. Bruno de Menezes: traços biográficos. In: ROCHA, Alonso; BASSALO, Célia Coelho; BOGÉA, J. Arthur; PEREIRA, João Carlos; INOJOSA, Joaquim. Bruno de Menezes ou a sutileza da transição: ensaios. Belém: CEJUP: UFPA, 1994. p. 9-36.

RODRIGUES, Carmem Izabel. Vem do bairro do Jurunas: sociabilidade e construção de identidades em espaço urbano. Belém: NAEA, 2008.

SIMMEL, Georg. A metrópole e a vida mental. In: VELHO, Otávio Guilherme (org.). O fenômeno urbano. Tradução: Sérgio Marques dos Reis. 2. ed. Rio de Janeiro: Zahar, 1973. p. 11-25.
WANZELER, Rodrigo de Souza. Bruno de Menezes: fragmentos de memórias (des)contruindo histórias de vida de um literatoetnógrafo. In: ENCONTRO NACIONAL DE HISTÓRIA ORAL, 13., 2016, Porto Alegre. Anais [...]. Porto Alegre: UFRGS, 2016. p. 1-17. Disponível em: http://www.historiaoral.org.br/resources/ anais/13/1461872632 ARQUIVO ARTIGOHISTORIAORAL-POA. pdf. Acesso em: 15 mar. 2019.

WANZELER, Rodrigo de Souza; PACHECO, Agenor Sarraf. Bruno de Menezes, etnógrafo da Amazônia: zonas interculturais em Boi Bumbá - auto popular. Revista FSA, Teresina, v. 13, n. 1, p. 25-44, jan./fev. 2016. DOI: http://dx.doi.org/10.12819/2016.13.1.2. 
